\title{
ABNORMAL RELATED PARTY TRANSACTIONS, POLITICAL CONNECTION, AND FIRM VALUE: EVIDENCE FROM INDONESIAN FIRMS
}

\author{
Supatmi Supatmi* \\ Satya Wacana Christian University \\ Sutrisno Sutrisno \\ Brawijaya University \\ Erwin Saraswati \\ Brawijaya University \\ Bambang Purnomosidhi \\ Brawijaya University
}

\begin{abstract}
This study aims to examine the effect of abnormal related party transactions (RPTs) on firm value and to investigate political connections as a moderator of the causal relationship. Our sample is 450 Indonesian firms listed at the Indonesia Stock Exchange during the period of 2014-2017 with a total of 1,724 firm-year observations. Based on the panel data regression test, our results demonstrate that abnormal RPTs, especially account receivables-related RPTs and account payables-related RPTs, decrease firm value. Further, the results empirically show that political connections negatively affect firm value. Political connections strengthen the effects of abnormal non-account receivable RPT assets and abnormal non-account payable RPT liabilities on firm value. Our findings imply that agency theory explains the impacts of political connections of Indonesian firms better than resource dependence theory.
\end{abstract}

Keywords: Abnormal Related Party Transaction, Political Connection, Firm Value, Agency Theory, Resource Dependence Theory, Indonesia.

Received: 10 July 2019

Accepted: 30 December 2020

https://doi.org/10.33736/ijbs.3189.2021

\section{INTRODUCTION}

According to the Indonesian Statement of Financial Accounting Standard No. 7 (Pernyataan Standar Akuntansi Keuangan/PSAK No. 7), the measurement of firms' accounting performance is susceptible to agency conflicts, including the presence of related party transactions (IAI, 2016). In this respect, majority shareholders potentially abuse related party transactions (RPTs) to

\footnotetext{
* Corresponding author: Faculty of Economics and Business, Satya Wacana Christian University, Diponegoro Street 52-60 Salatiga, Central Java, Indonesia. E-mail patmie@staff.uksw.edu or supatmi.supatmi@uksw.edu
} 
expropriate minority shareholders' interests (Friedman, Johnson, \& Mitton, 2003). RPTs are commonly found in group-based firms, especially in Asia (Wong, Kim, \& Lo, 2015), including in In donesia (Utama, Utama, \& Yuniasih, 2010).

The RPT potentially have both positive and negative impacts on firms. For example, according to the efficient transaction hypothesis, the RPTs make firms' transactions more efficient (Gordon, Henry, \& Palia, 2004) that will eventually enhance firm performance (propping up) (Cheung, Jing, Lu, Rau, \& Stouraitis, 2009). In a similar vein, the RPTs likely reduce transaction costs (Tsai, Chang, \& Chang, 2015) and increase firm value (Utama \& Utama, 2014). In contrast, the RPTs also create conflicts of interests between majority and minority shareholders (conflict of interest hypothesis) (Gordon et al., 2004) and enable the majority shareholders to expropriate the minority shareholders (tunneling) (Cheung et al., 2009). Further, firms also use the RPTs as earning management practices (Jian \& Wong, 2003) that decrease the firm performance (Wahab, Haron, Lok, \& Yahya, 2011).

According to Pizzo (2013), the RPTs were affected by the firms' corporate governance practices, especially the role of the board of directors (BOD) ${ }^{1}$. Politically connected boards are a linkage type of board of directors (BOD) that affects the firms' transactions (Chen, Ariff, Hassan, \& Mohamad, 2013). Previous studies indicate that the politically connected firms perform differently than non-politically connected firms (Hillman, 2005; Faccio, 2010; Chen et al., 2013). According to the resource dependence theory, the presence of politicians in BODs is a corporate political strategy that delivers positive effects to the firms (Hillman, 2005). Conversely, from the agency theory perspective, the politically connected firms are potentially risk takers (Ling, Zhou, Liang, Song, \& Zeng, 2016).

This study aims to find the empirical evidence on the effect of abnormal RPTs on the firm value of Indonesian public firms and to examine whether political connection strengthens the causal relationship. By using Indonesian data, Habib, Muhammadi, and Jiang (2017) empirically demonstrated that Indonesian firms used net account receivables-related RPTs to expropriate firms' resources, especially for the ones that are closely connected to the government. Meanwhile, Supatmi, Sutrisno, Saraswati, \& Purnomosidhi (2019) found that the account receivables-related (account payables-related) RPTs positively (negatively) affected the firm value of Indonesian banking firms, and the political connections moderated the causal relationship. In contrast to previous studies, this study uses five types of RPTs on account and group level (account receivable, account payable, sales, non-account receivable RPT assets, non-account payable RPT liabilities) measured using abnormal RPT (Jian \& Wong, 2010). Besides, we also measure the level of political connections in more detailed based on the position of each politically connected personnel by modifying Supatmi et al., (2019), and not only based on their presence as in Habib et al., (2017).

To investigate the research questions, we run a panel regression analysis on 1,724 firm-year observations of 450 firms listed at the Indonesia Stock Exchange (IDX) from 2014 to 2017. The results show that the abnormal related party transactions negatively affect the firm value. Further,

\footnotetext{
1 In countries with a two-tier board system, board of directors (BOD) is classified into two groups, namely supervisory board and executive board. Meanwhile, for firms in countries with a one-tier system, the roles of supervisory board and executive board are combined into a single board called board of directors or simply board (Ticker 2009 in Rasyidah, 2013).
} 
the level of political connections also negatively affects the firm value and strengthen the negative impact of abnormal RPTs on the firm value.

This research offers at least four contributions. First, we add empirical evidence on the application of agency theory by showing the effect of RPTs on the firm value in Indonesia. Indonesia offers a suitable setting for this research issue because a large number of Indonesian public firms are family-controlled (Claessens, Djankov, \& Lang, 2000) and it has a weak investor protection mechanism (Leuz \& Oberholzer-Gee, 2006; Habib et al., 2017). The conditions likely expose the Indonesian firms to the agency conflicts between the majority and minority shareholders (Villalonga \& Amit, 2006), where the majority shareholders have greater incentives and ability to exploit the RPTs to expropriate. Second, this study also adds literature on RPTs and political connection in emerging market countries such as Indonesia. The results also confirm that the effect of RPTs on firm value may be related to the RPT on account level or group account of certain RPT. The political dynamics in Indonesia show that there are more entrepreneurs who are interested in politics under the governance of Joko Widodo-Jusuf Kalla which makes this issue more interesting to be studied on its effects on the causal relationship of RPT and firm value. Third, this paper contributes by showing the impact of abnormal RPTs on firm value. The abnormal RPTs facilitate greater management's involvement that makes firm vulnerable to expropriation because the transactions are relatively small in terms of amount, less disclosed, and not subject to regulators and public oversight bodies (Utama et al., 2010). Additionally, previous studies that are indicated before largely use normal RPTs. Fourth, we measure the level of political connections in more detailed based on the position of each politically connected personnel by modifying Supatmi et al., (2019). The measure arguably offers a different perspective and explains the impact of political connections better than previous studies that largely measure the variable by using a dummy or by counting the number of politically connected personnel.

The following part of this paper presents the theoretical review and hypothesis development. The discussion of the research methods used in this study follows. Next, we present and discuss the results, including the result of sensitivity test. The last part concludes and offers implications and suggestions for future research.

\section{LITERATURE REVIEW AND HYPOTHESIS DEVELOPMENT}

\subsection{RPT in Indonesia and ASEAN}

According to PSAK No. 7, related party transactions (RPTs) refers to a transfer of resources, services, or obligations between related parties, regardless of whether a price is charged. In Indonesia, the Financial Services Authority (Otoritas Jasa Keuangan (OJK)) and Capital Market and Financial Institution Supervisory Agency refer RPTs to affiliated transactions - transactions made by companies or conrolled companies with affiliates from companies or affiliates of members of the board of directors (BOD), members of the board of commissioners, or major shareholders of the company. Since 2000 renewed 2010, OJK (2010) states that public companies must disclose the RPTs, for either the types, values / balances, policies, and assumptions related to the transaction. Starting in 2009 through OJK (2009), it was stated that public companies conducting RPTs must disclose it to the public no more than two days since the event occurred, except the RPT value is less than 0.5 percent of paid up capital and not more than five billion rupiah. 
Several research results with a sample of companies in Indonesia show that RPTs could have a negative or positive impact on the company performance. Utama et al., (2010) prove that there is no difference in market reactions between companies that announce the RPTs and non-RPTs. However, the market reacts negatively when the announcement of RPT information is estimated as a way to conduct expropriation (tunneling), and responded positively by markets that associate RPTs as efficient (propping). Utama and Utama (2014) find that the RPTs related to assets have a negative effect on the firm value (price book value), while loan receipts from related parties have a positive effect on the firm value.

A study by Tambunan, Martua, Siregar, Manurung, and Priyarsono (2017) used quarterly financial data from 22 companies belonging to three company groups in Indonesia, such as Astra, Lippo, and Bakrie. They found that the RPTs related to loans and receivables had a negative effect on the firm value (Tobin's Q), but the RPTs, purchases, and expenses had a positive impact on the firm value. Furthermore, the research results by Habib et al., (2017) also confirmed that companies that tunneled through the RPTs for loans or receivables were more involved in managing earnings to cover the takeovers.

The results of research in other countries in ASEAN find similar results. Wahab et al., (2011) used a public company in Malaysia and found that the RPTs, both the number of transactions and its amount, negatively affect the firm performance. These negative effects could be mitigated by corporate governance mechanisms either through the level of independent commissioners, higher executive remuneration, and if it was audited by the Public Accounting Firm included in the big four. A research by Downs, Ooi, Wong, and Ong (2016) on the property market in Hong Kong, Malaysia and Singapore found an average of 5.4\% of the total assets of companies in relation to the RPTs. Many RPTs were carried out using 3 channels, including real estate asset acquisitions from related parties $(57.4 \%)$, income earned from related parties $(22.2 \%)$ and management fees paid to related parties (14.8\%). The RPT acquisitions were found to have a positive effect on the firm value.

\subsection{Abnormal RPTs and Firm Value}

According to the agency theory, firms tend to use RPTs for tunneling and not for propping, especially when a majority shareholder exists. Sari, Fatimah, and Djajadikerta (2016) explained that concentrated ownership was more likely to engage in tunneling transactions than dispersed ownership. The RPTs would reduce, and not increase, the value of Indonesian firms.

Similar to the earnings management, firms can engage in both normal and abnormal RPTs (Jian \& Wong, 2010). Previous studies largely used normal RPTs as measured with information disclosure or the amount of RPTs as disclosed in the financial statements. However, the abnormal RPTs are easier to exploit for the expropriation purpose than for efficiency because they are usually small in amount, less disclosed, and less subject to the regulators and other public oversight bodies (Utama et al., 2010). Consequently, they are susceptible to expropriation. Thus, they can increase the expropriation of minority shareholders' interests (Jian \& Wong, 2010; Wong et al., 2015).

Several studies empirically demonstrate that the RPTs harmed firm value. For example, in China, related party lending (Jian \& Wong, 2003), issuance of debt guarantees for related parties 
(Berkman, Cole, \& Fu, 2009), and RPTs in sales, loans, guarantees, and mortgages or leases (Chen, Chen, \& Chen, 2009) decreased the firm value. Similarly, the findings of Gordon et al. (2004) in the United States, Wahab et al. (2011) in Malaysia, and Lin, Liu, and Keng (2010) in Taiwan indicated that the majority shareholders used the RPTs to expropriate the minority shareholders' interests. In Indonesia, Utama et al. (2010), Utama and Utama (2014), and Tambunan et al. (2017) showed that the RPTs, especially the provisions of loans or receivables to related parties, harmed the firm value. Lastly, Supatmi et al. (2019) also confirmed that banks that engaged more in the account payables-related RPTs exhibited lower firm value. Based on the arguments, we propose the following hypothesis:

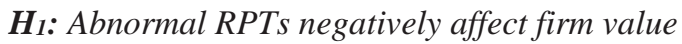

\subsection{Abnormal RPTs, Political Connections, and Firm Value}

A firm is considered politically connected if at least one of its board members or significant shareholders is or was a parliamentary member or a head of state (Faccio, 2006); a member of military service (Habib et al., 2017); a senior officer at ministries or other governmental agencies or a head of a regional government unit ( $\mathrm{Wu}, \mathrm{Wu}, \mathrm{Zhou}, \& \mathrm{Wu}, 2012$ ); is closely related to politicians or political parties, or has a friendship relationship with them, including their close families (Faccio, Masulis, \& McConnel, 2006). A political connection is arguably a precious resource of many firms (Fisman, 2001) because the politically connected boards provide numerous facilities for their firms in engaging transactions (Faccio, 2006).

According to the resource dependence theory, the politically connected boards will reduce transaction costs, increase firms' endurance, and accelerate firms' business transactions (Hillman, 2005). For example, politically connected firms often receive loans with lower interest rates from state-owned banks (Houston, Jiang, Lin, \& Ma, 2014), have better access to credit (Leuz \& Oberholzer-Gee, 2006), have lower cost of equity (Boubakri, Guedhami, Mishra, \& Saffar, 2012), pay less taxes (Adhikari, Derashid, \& Zhang, 2006; Wu et al., 2012), and are less likely to receive legal sanctions from regulators (Sun, Hu, \& Hillman, 2016). Conversely, according to the agency theory, the politically connected boards use RPTs to expropriate firms' resources for their interests (Habib et al., 2017) and increase block holder rent appropriation (Sun et al., 2016). Specifically, the politically connected firms exhibit lower productivity (Domadenik, Prašnikar, \& Svejnar, 2016), make excessive investments (Ling et al., 2016), and prefer diversification activities that are less related to their core businesses that worsen their long-term performance (Deng, Tian, Li, \& Abrar, 2012).

This study predicts that the firms' political connections will affect their value and strengthen the causal relationship between abnormal RPTs and firm value. The firms' political connections will weaken the effectiveness of regulations, and make RPTs to be more a "hand-grabbing" mechanism than a "helping-hand" one for the connected firms (Cheung, Rau, \& Stouraitis, 2010). Liu, Uchida, and Yang (2012) demonstrated that the political connections in Chinese SOEs aimed to use the RPTs to expropriate firms' resources for the interests of non-firm state stakeholders. Further, Habib et al. (2017) revealed that the politically connected firms were more likely to use the RPTs to extract firms' resources (tunneling) than the non-politically connected ones. Lastly, in Indonesia, the political connections moderate the impact of RPTs on the firm value of Indonesian banks (Supatmi et al., 2019). Based on the arguments, we propose the following hypotheses: 


\section{$\boldsymbol{H}_{2}$ : Political connections affect firm value}

\section{$\boldsymbol{H}_{3}$ : Political connections strengthen the influence of abnormal RPTs on firm value}

\section{RESEARCH METHOD}

This study uses 450 firms listed at Indonesia Stock Exchange (Bursa Efek Indonesia) during the period of 2014-2017 with a total of 1,724 firm-year observations that are spread into nine industries. Based on the corporate action data of issuers on the Indonesia Stock Exchange during the study period (www.ojk.go.id), the RPTs - which are affiliated transactions - are the most frequent corporate actions carried out by issuers (an average of 60 percent of total corporate actions). In 2014, it was the first year of President Joko Widodo's administration. Before becoming a politician, he was a businessman. It is in contrast to the previous president who were generally military or politician-based. The cabinet he drafted also included many elements of entrepreneurs that made the political connections with business increasingly visible, so that they could provide a better picture of RPT relations, political connections and corporate value.

We relied on the firms' annual reports as the main data source together with market share data and the detailed information on the politically connected boards. We generated our data from (www.idx.co.id) and other related websites to verify the measure of politically connected boards.

We used Tobin's Q as the proxy of firm value as the dependent variable. We measured the Tobin's $\mathrm{Q}$ by dividing the end-of-year market value of a firm's assets with the end-of-year book value of a firm's assets. The market value of a firm's assets is the addition of the book value of total debts and the end-of-year market value of outstanding stock equity (Berkman et al., 2009).

In this paper, we use three types of RPTs, such as account receivables-related RPTs (RPT_ARRES), account payables-related RPTs (RPT_APRES), and sales-related RPTs (RPT_SALESRES) that represent accounts that are directly related to the firms' main activities. This study also uses non-account receivable RPT assets (RPT_NARRES) and non-account payable RPT liabilities (RPT_NAPRES) to accommodate other RPTs in the financial statement positions. We adopt Jian and Wong (2010) in measuring the amount of abnormal RPTs as the independent variable. Specifically, the study uses the residual value of the regression of specific RPTs on firm size (measured with the natural logarithmic value of end-of-year stock market capitalization), leverage level (measured with total liabilities divided by total assets), and firm growth rate (measured with equity market value divided by equity book value). For example, abnormal account receivables-related RPTs (RPT_ARRES) is generated by regressing the account receivablesrelated RPTs on firm size (SIZE), leverage level (LEV), and firm growth rate (GROWTH) or mathematically formulated as RPT_ARRES $=\alpha_{0}+\alpha_{1} S I Z E+\alpha_{2} L E V+\alpha_{3} G R O W T H+\varepsilon$.

The political connections are measured by the political connection index measured using the natural logarithmic value of the total score of a firm's political connections plus one or mathematically formulated as $\mathrm{LN}(\mathrm{PCI})=\mathrm{LN}(1+\mathrm{PCI})$. In this respect, we refer to Supatmi et al. (2019) who also adopted Faccio (2006), Faccio et al. (2006), Wu et al. (2012) and Habib et al. (2017) in defining the political connections. However, this research makes two modifications. First, we add the criteria of politically connected personnel by referring to other previous studies, such as Leuz and Oberholzer-Gee (2006) and Fisman (2001). Second, we do not measure the 
position levels of politically connected individuals based on the hierarchical position in ministries but on the hierarchy of structural position in government, i.e., the status of Indonesian civil servants classified into echelons. The score of politically connected personnel of firms ranges from 2 (the lowest level - echelon IV and V or equivalent) to 9 (the highest level - the president or vice president) for those who still actively hold the position in the current periods. The score of inactive politically connected personnel (ex-officer) ranges from 1 (the lowest level) to 8 (the highest level). The non-politically connected firms will be scored 0. Appendix A presents examples of the political connection indexes of several firms.

Further, we also include several control variables in the analysis. The block holder ownership is measured with the percentage of share ownership of the largest shareholder (Sun et al., 2016). We include firm size in the analysis and measure it using the natural logarithmic value of a firm's endof-year stock market capitalization. Next, we use a dummy variable of the audit firm type as the proxy of audit quality. Specifically, the dummy variable is equal to 1 if a firm is audited by a Big4 affiliated audit firm and 0 otherwise. Last, we measure the leverage by dividing total liabilities with total assets.

This study combines both cross-section and time-series data. Consequently, we use the Eviews software to run the panel data regression analysis. The following are the regression equations:

\section{Model 1}

$$
F V_{i t}=\alpha_{0 i t}+\alpha_{1} R P T_{i t}+\alpha_{2} P C I_{i t}+\alpha_{3} B L O C K_{i t}+\alpha_{4} S I Z E_{i t}+\alpha_{5} A U D_{i t}+\alpha_{6} L E V_{i t}+\varepsilon_{i t}
$$

\section{Model 2}

$$
\begin{gathered}
F V_{i t}=\beta_{i t}+\beta_{1} R P T_{i t}+\beta_{2} P C I_{i t}+\beta_{3} R P T_{i t} \times P C I_{i t}+\beta_{4} B L O C K_{i t}+\beta_{5} S I Z E_{i t}+\beta_{6} A U D_{i t} \\
+\beta_{7} L E V_{i t}+\varepsilon_{i t}
\end{gathered}
$$

Model 1 examines hypothesis 1 and 2. We tested hypothesis 3 with the hierarchical analysis dependen (Hair, Black, Babin, \& Anderson, 2014). Furthermore Hair et al. (2014) stated that to determine whether the moderator effect is significant or not. The researchers follows a three-step process as follows: (1) estimate the original (unmoderated) equation; (2) estimate the moderated relationship (original equation plus moderator variable); and (3) assess the change in $R^{2}$ : If it is statistically significant, then a significant moderator effect is present. Only the incremental effect is assessed, not the significance of individual variables. A multiple testing helps to understand the changes as a result of before and after the moderating variable and to understand whether the effect of moderating variable is strengthening or weakening. Therefore, in this study, the multiple testing is used to prove whether the political connection could act as a moderating variable in the causal relationship between RPT and firm value by comparing model 1 (without moderation) and model 2 (with moderation). The results confirm that the political connection strengthens the effect of RPT on the firm value if $\mathrm{R}^{2}$ model $2>\mathrm{R}^{2}$ model 1 , the regression coefficient value of RPT interaction and political connections $\left(\beta_{3}\right)$ is significant, and $\beta_{1}>\alpha_{1}$.

For the sensitivity analysis, this study also runs two additional tests. First, we divide the sample into two subsamples: firms in the financial industry and in the non-financial industry, to analyze the effect of industry variation on the results. Second, we convert the political connection index (PCI) measure into a dummy variable (political connection is present/ absent) to examine the effect of the different measurement approaches of the political connection variable on the results. 


\section{RESULTS AND DISCUSSIONS}

Table 1 presents the distribution of the research data. Based on Table 1, the mean value of TOBIN that is greater than one (1.62) indicates that on average, the investors valued the firms' shares higher than their book value.

Table 1: Descriptive Statistics

\begin{tabular}{lrrrr}
\hline \hline \multicolumn{1}{c}{ Research Variable } & \multicolumn{1}{c}{ Maximum } & Minimum & \multicolumn{1}{c}{ Mean } & Standard Deviation \\
\hline TOBIN & 37.231 & 0.199 & 1.616 & 2.131 \\
RPT_ARRES & 0.212 & -0.019 & -0.000 & 0.029 \\
RPT_NARRES & 0.391 & -0.050 & -0.000 & 0.059 \\
RPT_APRES & 0.795 & -0.049 & -0.000 & 0.055 \\
RPT_NAPRES & 0.528 & -0.072 & -0.000 & 0.088 \\
RPT_SALESRES & 1.444 & -0.083 & -0.000 & 0.135 \\
PCI & 4.248 & 0 & 1.498 & 1.289 \\
BLOCK & 0.999 & 0.050 & 0.502 & 0.216 \\
SIZE & 33.912 & 20.669 & 28.126 & 1.982 \\
LEV & 3.413 & 0.000 & 0.531 & 0.307 \\
\hline \hline
\end{tabular}

\section{Research Variable}

No. of

Proportion

Observations

Audit Quality (AUD)

Big 4 Audit Firm (1)

650

$37.70 \%$

Non-Big 4 Audit Firm (0)

1,074

$62.30 \%$

The Presence of Political Connections (PCIDUM)

Present

1,078

$62.53 \%$

Not Present

646

$37.47 \%$

Notes: TOBIN: Tobins'Q value; RPT_ARRES: abnormal account receivables-related RPTs; RPT_NARRES: abnormal non-account receivables RPT assets; RPT_APRES: abnormal account payables-related RPTs; RPT_NAPRES: abnormal non-account payable RPT liabilities; RPT_SALESRES: abnormal sales-related RPTs; PCI: political connection index; BLOCK: block holder ownership; SIZE: firm size; LEV: leverage; AUD: audit quality; PCIDUM: the presence of political connections

We also find that the sample firms exhibit relatively low RPTs that are measured with the residual value of the regression of RPT amount against firm size, leverage level, and firm growth. From all types or RPTs, the highest values range from $21.2 \%$ to $144.4 \%$ from firms' total asset or liabilities. Several firms even did not engage in RPTs during the observation period.

In the political connection index (PCI), the mean value of firms' PCI is 1.49 or equal to a political connection score of 4 (four). From 1,724 firm-year observations, only $62.53 \%$ of them exhibit political connection, and the rest (37.47\%) do not have any. The firms' political connections were mostly related to the presence of board members, especially supervisory board ones, who were exministers or senior government officers who previously held positions of echelon I. The politically connected board members in a firm also held positions as board members in other firms that were in the same firm group, such as Lippo group, Sinar Mas group, Bakrie group, and Astra group. Most politically connected supervisory board members were independent supervisory directors that also acted as the heads of the audit committee. The findings indicate that the firms considered the politically connected boards to provide legitimation benefits, as suggested by the resource 
dependence theory perspective (Hillman, 2005). Specifically, the firms also tried to comply with the regulations on the presence of independent supervisory directors (commissioners) and audit committee as a good corporate governance practice. In this respect, the complying firms were less likely to receive sanctions from the regulators (Sun et al., 2016).

Further, about $50.2 \%$ of the firms' outstanding shares are owned by their single largest shareholders, either institutional or individual ones. The sample firms are also highly leveraged (the mean score of leverage is $53.1 \%$ ), and the mean score of firm size (measured with the natural logarithmic value of market capitalization) is 28.13 . Besides, most firms $(62.3 \%)$ are audited by non-Big 4 audit firms.

By using the F-Test (Chow Test), Hausman Test, and Lagrange Multiplier (LM) Test to determine the appropriate estimation technique for our panel data regression model, we find that the Random Effect Model (RE) was the appropriate estimation technique for our panel data regression model to test the hypotheses. Below, Table 2 provides a summary of the test result.

Table 2: Result of Estimation Technique Test of Panel Data Regression Model

\begin{tabular}{cccc}
\hline \hline $\begin{array}{c}\text { Regression } \\
\text { Equation }\end{array}$ & $\begin{array}{c}\text { Chow Test (Cross } \\
\text { section Chi- } \\
\text { square) }\end{array}$ & $\begin{array}{c}\text { Hausman Test } \\
\text { (Cross-section } \\
\text { random) }\end{array}$ & $\begin{array}{c}\text { Langrange Test } \\
\text { (Breusch-Pagan, both) }\end{array}$ \\
\hline Model 1 & $3662.53 * * *$ & $48.70^{* * *}$ & $1663.16^{* * * *}$ \\
Model 2 & $3619.74 * * *$ & $58.13 * * *$ & $1641.52^{* * * *}$ \\
\hline \hline
\end{tabular}

Notes: $*, * *, * * *$ : significant at a significance level of $10 \%, 5 \%, 1 \%$, respectively

In addition, this study uses panel data that has a smaller amount of time ( $\mathrm{T}$ ) than the number of individuals $(\mathrm{N})$. Therefore, it is recommended to use Random Effect method (Gujarati \& Porter, 2009). Based on the results of the data stationarity test and the four classical assumptions (diagnostic tests), including normality, autocorrelation, multicollinearity, and heteroscedasticity, the assumptions can be fulfilled except the normality of the data. Below, Table 3 presents a summary of the results of this test.

Table 3: Result of Diagnostic Tests

\begin{tabular}{|c|c|c|c|c|c|}
\hline $\begin{array}{c}\text { Regression } \\
\text { Equation }\end{array}$ & $\begin{array}{c}\text { Normality } \\
\text { Test } \\
\text { (prob. } \\
\text { Jarque-Bera) }\end{array}$ & $\begin{array}{l}\text { Autocorrela- } \\
\text { tion Test } \\
\text { (Durbin- } \\
\text { Watson stat/ } \\
d \text { ) }\end{array}$ & $\begin{array}{c}\text { Multicolinearity } \\
\text { Test (correlation } \\
\text { value between } \\
\text { variables }>0.8 \text { ) }\end{array}$ & $\begin{array}{c}\text { Heteroscedas- } \\
\text { ticity Test - } \\
\text { Park Test } \\
\text { (parameter } \\
\text { coefficients for } \\
\text { each } \\
\text { independent } \\
\text { variable) }\end{array}$ & $\begin{array}{l}\text { Stationary } \\
\text { Test (prob. } \\
\text { PP-Fisher } \\
\text { Chi-square) }\end{array}$ \\
\hline Model 1 & $957906.5 * * *$ & 1.62 & Absent & Insignificant & $1826.04 * * *$ \\
\hline Model 2 & $989277.8 * * *$ & 1.62 & Absent & Insignificant & $1788.29 * * *$ \\
\hline
\end{tabular}

Notes: *, **, ***: significant at a significance level of $10 \%, 5 \%, 1 \%$, respectively

According to Central Limit Theorem (CLT), a large number of samples (such as more than 30) can be considered to have a normal distribution (Islaqm, 2018). The greater the number of samples, the closer to the normal distribution. Similar opinion was also stated by Chandrarin (2017) that 
naturally, large amounts of data could or tend be normally distributed. This study uses a sample of 450 companies from 596 companies listed on the Indonesia Stock Exchange during the period of $2014-2017$ or $75.5 \%$ of the population with a total of 1,724 observations $(80.11 \%$ of the total observations of 2,152). Based on the CLT, the number of samples used in this study can be considered large, so that the data are normally distributed. In addition, according to Gujarati and Porter (2009), if the estimation technique of the right panel data regression model is the Random Effect Model, the fulfillment of the classical assumption test is not absolute because the Generalized Least Squares (GLS) estimator in the random effect model is BLUE (best linear unbiased estimator). Thus, the hypothesis testing of this research can still be continued although the data meet the assumptions of the autocorrelation, multicollinearity, heteroscedasticity, and stationarity test but do not pass the normality test. The following Table 4 displays a summary of the results of hypothesis testing.

Table 4: Hypothesis Testing

\begin{tabular}{|c|c|c|}
\hline \multirow{2}{*}{ Research Variable } & \multicolumn{2}{|c|}{ "Firm Value (TOBIN) } \\
\hline & Model 1 & Model 2 \\
\hline Constant & $-11.128 * * *$ & $-11.071 * * *$ \\
\hline RPT_ARRES & $-3.569 * *$ & $-3.930 *$ \\
\hline RPT_NARRES & 0.502 & $1.828 * *$ \\
\hline RPT_APRES & $-2.058 * * *$ & $-2.249 * *$ \\
\hline RPT_NAPRES & -0.082 & $-1.293 * *$ \\
\hline RPT_SALESRES & 0.017 & -0.008 \\
\hline PCI & $-0.106^{* *}$ & $-0.102 * *$ \\
\hline RPT_ARRES*PCI & & 0.662 \\
\hline RPT_NARRES*PCI & & $-0.822 * *$ \\
\hline RPT_APRES*PCI & & 0.089 \\
\hline RPT_NAPRES*PCI & & $0.922 * * *$ \\
\hline RPT_SALESRES*PCI & & -0.062 \\
\hline BLOCK & -0.306 & -0.310 \\
\hline SIZE & $0.457 * * *$ & $0.455 * * *$ \\
\hline AUD & $-0.408 * * *$ & $-0.408 * * *$ \\
\hline LEV & $0.927 * * *$ & $0.906 * * *$ \\
\hline Year effect & Yes & Yes \\
\hline $\mathrm{R}^{2}$ & 0.146 & 0.152 \\
\hline Adjusted $\mathrm{R}^{2}$ & 0.140 & 0.144 \\
\hline F-statistic & $26.604 * * *$ & $19.138 * * *$ \\
\hline
\end{tabular}

Notes:

a) $\quad *, * *, * * *$ : significant at a significance level of $10 \%, 5 \%, 1 \%$, respectively

b) See Table 1 for the variable definitions.

Based on Table 4 , the adjusted $\mathrm{R}^{2}$ score is 0.14 , indicating that all independent variables statistically explain $14 \%$ of the variance proportion of firm value (TOBIN) while the rest $(86 \%)$ is explained by other factors not investigated in this study. The low value of adjusted $\mathrm{R}^{2}$ is possibly because there were indeed many factors that affected the firm value, especially the ones in relation to determining the market price of the company's shares that could be influenced by internal and external factors. Nevertheless, the value is far above the minimum required adjusted $\mathrm{R}^{2}$ of only $2 \%$ for regression testing with the number of independent variables $\leq 10$ with a sample size of 1,000 (Hair et al., 2014). Together with the value of F statistic and its significance, the value of adjusted 
$\mathrm{R}^{2}$ as the coefficient of determination statistically indicates that the regression function for hypothesis testing qualifies for the goodness of fit model.

In Table 4, model 1 shows that the account receivables-related RPTs (RPT_ARRES) and account payables-related RPTs (RPT_APPRES) negatively affect firm value. The firms that engaged more in the abnormal account receivables- and account payables- related RPTs likely had a lower firm value. Meanwhile, the non-account receivable RPT assets (RPT_NARRES), non-account payable RPT liabilities (RPT_NAPRES), and sales-related RPTs (RPT_SLAESRES) did not affect the firm value. Thus, the findings support $\mathrm{H} 1$ for the abnormal account receivables- and account payablesrelated RPTs.

The findings also demonstrate that the investors, as market participants, considered the abnormal RPTs, especially account receivables- and account payables- ones, expropriation actions that only benefited the firms' controlling shareholders and not the firms themselves (Johnson, LaPorta, Lopez-de-Silanes, \& Shleifer, 2000; Sari et al., 2016) and consequently, the share prices declined. Further, the results confirm that the Indonesian firms that were family-controlled (Claessens et al., 2000; Habib et al., 2017) and exhibited principal conflicts (Sun et al., 2016) which motivated the firms to engage in the RPTs that contained potential conflicts of interests and eventually reduced firm performance. Our findings also support the conflict of interest hypothesis as suggested by Gordon et al. (2004) that the RPTs likely created conflicts of interests between the majority and minority shareholders. The study is in line with Jian \& Wong (2003), Cheung et al., (2009), Gordon et al., (2004), Kohlbeck \& Mayhew (2010), Nekhili \& Cherif (2011), and Tambunan et al., (2017) who found that the account receivables-related RPTs negatively affected the firms' market performance.

Meanwhile, in both model 1 and model 2, the abnormal sales-related RPTs do not affect the firm value. The positive value of the coefficient regression indicates that such RPTs positively affected the firm value. Besides, the findings indicate that the account receivables- and sales-related RPTs, and non-account receivable RPT assets were more propping mechanisms instead of the tunneling one. In other words, these RPTs increased the efficiency of transaction costs (efficient transaction hypothesis) (Gordon et al., 2004). The sales, including sales-related RPTs, were recurring and easily detectable that it was difficult for the managers to manipulate (Wong et al., 2015), especially if the cash sales dominated the sales transactions (Jian \& Wong, 2010). Both investors and managers arguably predicted the amount and the impact of sales-related RPTs on firms' net income at the end of years. The quarterly financial statements helped the managers and investors to make these predictions. The arguments explained why the abnormal sales-related RPTs did not significantly affect the firm value.

In Table 4, both model 1 and model 2 show that the political connections negatively affect the firm value. Firms with more political connections had a lower value, thus supporting $\mathrm{H} 2$. The results also support the agency theory that argues that the political connections would have a negative effect on firms. From the agency theory perspective, the politically connected firms tended to be risk takers (Ling et al., 2016) and were more likely to experience business failures. Consequently, the investors negatively reacted to the firms' political connection as indicated by reduced share prices. 
On average, the politically connected firms are more leveraged $(61.86 \%)$ than non-politically connected firms $(54.59 \%)$. Thus, the politically connected firms incurred higher interest rates and consequently were riskier. Our findings support support Sun et al. (2016) and Ling et al. (2016) and suggest that the politically connected firms were more leveraged and incurred greater underperformance risk (Deng et al., 2012).

This study uses the multiple testing developed by Hair et al. (2014) to examine the political connections as a moderating variable in the causal relationship between RPT and firm value by comparing model 1 (without moderation) and model 2 (with moderation). The political connections are confirmed to strengthen the effect of RPT on firm value if the value of $\mathrm{R}^{2}$ model $2>\mathrm{R}^{2}$ model 1 , the regression coefficient value of RPT interaction and political connections $\left(\beta_{3}\right)$ is significant, and $\beta_{1}>\alpha_{1}$.

In Table 4, model 2 demonstrates that the interaction between the abnormal non-account receivable RPT assets with political connections (RPT_NARRES*PCI) and the interaction between nonaccount payable RPT liabilities and political connections (RPT_NAPRES*PCI) have negative and positive regression coefficients at significance levels of $5 \%$ and $1 \%$ on firm value, respectively. The results suggest that the political connections moderated the effect of abnormal RPTs - as measured with the non-account receivable RPT assets and non-account payable RPT liabilities on the firm value. In this respect, the political connections partially moderated the effect of these RPTs on the firm value.

By comparing model 1 and model 2, we find that the regression coefficients for the effects of RPT_NARRES and RPT_NAPRES on firm value in model 2 (with moderation) are greater than in model 1 (without moderation). Specifically, the regression coefficients are respectively 1.828 and -1.293 (with moderation) and 0.502 and -0.082 (without moderation). We also find similar results for the regression coefficients of account receivables-related and account payables-related RPTs. The regression coefficients in the model with moderation are higher than the coefficients in the model without moderation. Thus, the firms with greater political connections exhibited stronger effects of abnormal RPTs on the firm value. Also, the determinant value $\left(\mathrm{R}^{2}\right)$ of model $2(0.152)$ is higher than $\mathrm{R}^{2}$ of model $1(0.146)$. Overall, $\mathrm{H} 3$ is empirically supported.

\section{SENSITIVITY TESTS}

This study runs two sensitivity tests. First, we divide the sample into two subsamples: firms in the financial industry and in the non-financial industry, to investigate the effect of industry variation on the results as presented in Table 5. Second, we convert the measure of political connection index (PCI) into a dummy variable (PCIDUM) that indicates the presence/ absence of political connections to examine the effect of the different measurement method of political connections on the results. Table 5 and 6 below present the results of the sensitivity tests. 
Table 5: Results of the First Sensitivity Test

\begin{tabular}{|c|c|c|c|c|}
\hline \multirow{3}{*}{ Research Variable } & \multirow{2}{*}{\multicolumn{2}{|c|}{$\begin{array}{c}\text { Non-Financial Industry } \\
367 \text { firms } \\
1403 \text { observations }\end{array}$}} & \multirow{2}{*}{\multicolumn{2}{|c|}{$\begin{array}{c}\text { Financial Industry } \\
83 \text { firms } \\
321 \text { observations }\end{array}$}} \\
\hline & & & & \\
\hline & Model 1 & Model 2 & Model 1 & Model 2 \\
\hline Constanta & $-12.607 * * *$ & $-12.467 * * *$ & $-4.065 * * *$ & $-4.861 * * *$ \\
\hline RPT ARRES & $-4.785 * *$ & $-4.177 *$ & 0.679 & 3.609 \\
\hline RPT_NARRES & 0.022 & $2.996 * * *$ & $3.720 * * *$ & -0.163 \\
\hline RPT_APRES & 0.295 & 0.904 & $-3.056 * * *$ & $-2.978 * *$ \\
\hline RPT_NAPRES & -0.238 & $-1.975 * * *$ & 0.402 & 0.453 \\
\hline RPT_SALESRES & 0.019 & -0.179 & -0.378 & -0.094 \\
\hline PCI & $-0.075 * * *$ & $-0.078 * * *$ & 0.004 & 0.038 \\
\hline RPT_ARRES*PCI & & 0.144 & & -2.184 \\
\hline RPT_NARRES*PCI & & $-1.427 * * *$ & & $2.147 * * *$ \\
\hline RPT_APRES*PCI & & -0.162 & & 0.069 \\
\hline RPT_NAPRES*PCI & & $0.779 * * *$ & & -0.729 \\
\hline RPT_SALESRES*PCI & & 0.097 & & 1.677 \\
\hline BLOCK & -0.099 & -0.168 & $-0.947 * *$ & $-0.977 * *$ \\
\hline SIZE & $0.501 * * *$ & $0.497 * * *$ & $0.241 * * *$ & $0.270 * * *$ \\
\hline AUD & $-0.387 * * *$ & $-0.386 * * *$ & $-0.463 * *$ & $-0.446 * *$ \\
\hline LEV & $1.181 * * *$ & $1.216^{* * *}$ & $-1.028 * *$ & $-1.072 * *$ \\
\hline Year effect & Yes & Yes & Yes & Yes \\
\hline $\mathrm{R}^{2}$ & 0.165 & 0.178 & 0.169 & 0.188 \\
\hline Adjusted $\mathrm{R}^{2}$ & 0.159 & 0.168 & 0.139 & 0.145 \\
\hline F-statistic & $25.049 * * *$ & $18.722 * * *$ & $6.814 * * *$ & $4.393 * * *$ \\
\hline
\end{tabular}

Notes:

a) $*, * *, * * *$ : significant at a significance level of $10 \%, 5 \%, 1 \%$, respectively

b) See Table 1 for the variable definitions.

Table 5 demonstrates that the results for the non-financial industry subsample are qualitatively similar to our previous findings. However, the financial industry subsample exhibits different results. Specifically, the abnormal non-account receivable RPT assets and abnormal account payable-related RPTs which negatively affect the firm value. Further, the political connections do not affect firm value in the financial industry subsample and only moderate the causal relationship between the abnormal non-account receivable RPT assets and firm value. The positive regression coefficients in the financial industry subsample indicate that the political connections positively affected the firm value in this industry while in the non-financial industry, the effect is negative. Besides, the changes in the $\mathrm{R}^{2}$ value (model 1 and model 2 ) in the financial industry are found to be greater than the changes in the ones in the non-financial industry. This finding implied that the political connections had more role as a moderating variable of the causal relationship between RPT and firm performance in the banking industry. The findings of this sensitivity analysis deserve further investigation. 
Table 6: Results of the Second Sensitivity Test

\begin{tabular}{crr}
\hline \hline \multirow{2}{*}{ Research Variable } & \multicolumn{2}{c}{ Firm value (TOBIN) } \\
\cline { 2 - 3 } Model 1 & Model 2 \\
\hline Constanta & $-11.005^{* * *}$ & $-10.871^{* * *}$ \\
RPT_ARRES & $-3.558^{* *}$ & $-5.269^{* *}$ \\
RPT_NARRES & 0.468 & 0.496 \\
RPT_APRES & $-2.067^{* * *}$ & $-1.885^{* *}$ \\
RPT_NAPRES & -0.119 & $-1.390^{* *}$ \\
RPT_SALESRES & 0.036 & 0.209 \\
PCIDUM & $-\mathbf{0 . 1 2 9}$ & $-\mathbf{0 . 0 8 7}$ \\
RPT_ARRES*PCIDUM & & 3.614 \\
RPT_NARRES*PCIDUM & & -0.282 \\
RPT_APRES*PCIDUM & & -0.294 \\
RPT_NAPRES*PCIDUM & & $2.297 * * *$ \\
RPT_SALESRES*PCIDUM & & -0.403 \\
BLOCK & -0.296 & -0.307 \\
SIZE & $0.450^{* * *}$ & $0.445^{* * *}$ \\
AUD & $-0.418^{* * *}$ & $-0.414 * * *$ \\
LEV & $0.921^{* * *}$ & $0.893^{* * *}$ \\
Year effect & Yes & Yes \\
R $^{2}$ & 0.144 & 0.149 \\
Adjusted R & 0.139 & 0.141 \\
F-statistic & $26.276^{* * *}$ & $18.743^{* * * *}$ \\
\hline \hline
\end{tabular}

Notes:

a. $* * *$, significant at a significance level of $10 \%, 5 \%, 1 \%$, respectively

b. See Table 1 for the variable definitions

Table 6 emphasizes that the presence of political connections in firms (PCIDUM) does not affect the firm value, while the political connection index (PCI) negatively affects the firm value (see Table 4). The findings show that measuring political connections based on the level of political connections according to the positions of politically connected personnel offers a better explanation on the causal relationships between RPTs, political connections, and firm performance, rather than just using a dummy variable (the presence / absence of political connections).

\section{CONCLUSIONS}

Based on the results of the analysis on the causal relationship between abnormal RPTs, political connections, and firm performance, we conclude that in general, the firms' political connections explain the inconsistent effects of RPTs on the firm performance. The firms engaging in more abnormal account receivables- or account payables-related RPTs have a lower value. The findings indicate that these abnormal RPTs were more a tunneling mechanism and support the conflict of interest hypothesis. The firms with greater political connections exhibit a lower value. Further, the political connections strengthened the effects of abnormal non-account receivable RPT assets and abnormal non-account payable RPT liabilities on the firm value. The Indonesian publicly listed firms engaging in the RPTs that were more likely to imply conflicts of interests (conflict of interest hypothesis) than the efficiency of transaction costs (efficient transaction hypothesis) for several reasons, such as weak investor protection and the common characteristics of these firms that were 
family-dominated and prone to agency conflicts between the majority and minority shareholders. Thus, the political connections in these firms arguably caused conflicts of interests (agency theory) and not a part of the firms' political strategy to reduce external risks (resource dependence theory).

As practical implications, the investors need to consider the significance of RPTs, especially those that are not clearly disclosed in the financial statements (abnormal) and firms' political connections in their investment decisions. This study demonstrates that the abnormal RPTs and political connections tend to trigger conflicts of interests and eventually reduce the firm value. Also, the political connections are able to strengthen the causal relationship between RPTs and firm value. Further, the results suggest the firms to take political connections in the composition of board members and the types and amount of RPTs into account to prevent their value from declining.

The determination and measurement of political connection levels are subjective. For some firmyear observations, we only managed to generate less detailed information on the profile of board members such as the (former) governmental positions of board members. For example, the profile information on several board members reveals that they worked at the Directorate General of Taxation, Ministry of Finance without detailing further the position of these board members. Consequently, we have to assume that these board members have the lowest political connection scores that might be not necessarily be in accordance with the true positions. This study also has not accommodated the period or terms served by the politically connected personnel in determining and measuring the level of political connections. Therefore, future researches are suggested to find better ways to trace the true position of each board member of a politically connected company and accommodate the position's terms.

\section{ACKNOWLEDGEMENT}

This work was supported by the Faculty of Economics and Business, Satya Wacana Christian University, Salatiga, Indonesia, where the first author works as a lecturer.

\section{REFERENCES}

Adhikari, A., Derashid, C., \& Zhang, H. (2006). Public policy, political connections, and effective tax rates: Longitudinal evidence from Malaysia. Journal of Accounting and Public Policy, 25, 574-595.

Berkman, H., Cole, R. A., \& Fu, L. J. (2009). Expropriation through loan guarantees to related parties: Evidence from China. Journal of Banking and Finance, 33, 141-156.

Boubakri, N., Guedhami, O., Mishra, D., \& Saffar, W. (2012). Political connections and the cost of equity capital. Journal of Corporate Finance, 18(3), 541-559.

Chandrarin, G. (2017). Accounting Research Methods Quantitative Approach (Metode Riset Akuntansi Pendekatan Kuantitatif). Jakarta: Salemba Empat.

Chen, C. M., Ariff, M., Hassan, T., \& Mohamad, S. (2013). Does a firm's political connection to government have economic value? Journal of the Asia Pacific Economy, 18(3), 477-501.

Chen, Y., Chen, C. H., \& Chen, W. (2009). The impact of RPTs on the operational performance of listed companies in China. Journal of Economic Policy Reform, 12(4), 285-297. 
Cheung, Y. L., Jing, L., Lu, T., Rau, P. R., \& Stouraitis, A. (2009). Tunneling and propping up: An analysis of RPTs by Chinese listed companies. Pacific Basin Finance Journal, 17, 372-393.

Cheung, Y. L., Rau, P. R., \& Stouraitis, A. (2010). Helping hand or grabbing hand central vs. Local government shareholders in Chinese listed firms. Review of Finance, 14(4), 669-694.

Claessens, S., Djankov, S., \& Lang, L. H. P. (2000). The separation of ownership and control in East Asian Corporations. Journal of Financial Economics, 58, 81-112.

Deng, X., Tian, Z., Li, J., \& Abrar, M. (2012). The diversification effects of a firm's political connection and its performance implications: Evidence from China. Chinese Management Studies, 6(3), 462-487.

Domadenik, P., Prašnikar, J., \& Svejnar, J. (2016). Political connectedness, corporate governance, and firm performance. Journal of Business Ethics, 139(2), 411-428.

Downs, D. H., Ooi, J. T. L., Wong, W. C., \& Ong, S. E. (2016). Related party transactions and firm value: Evidence from property markets in Hong Kong, Malaysia and Singapore. Journal of Real Estate Finance and Economics, 52(4), 408-427.

Faccio, M. (2006). Politically connected firms. American Economic Review, 96, 369-386.

Faccio, M. (2010). Differences between politically connected and non-connected firms: A cross country analysis. Financial Management, 39(3), 905-928.

Faccio, M., Masulis, R. W., \& McConnel, J. J. (2006). Political connections and corporate bailouts. The Journal of Finance, 61(6), 2597-2635.

Fisman, R. (2001). Estimating the value of political connections. The American Economic Review, 91(4), 1095-1102.

Friedman, E., Johnson, S., \& Mitton, T. (2003). Propping and tunneling. Journal of Comparative Economics, 31, 732-750.

Gordon, E. A., Henry, E., \& Palia, D. (2004). RPTs: Associations with corporate governance and firm value. EFA 2004 Maastricht Meetings Paper No. 4377. doi: 10.2139/ssrn.558983

Gujarati, D. N., \& Porter, D. C. (2009). Basic Econometrics (5th ed.). NewYork: McGraw-Hill/Irwin.

Habib, A., Muhammadi, A. H., \& Jiang, H. (2017). Political connections and RPTs: Evidence from Indonesia. The International Journal of Accounting, 52, 45-63.

Hair, J. F., Black, W. C., Babin, B. J., \& Anderson, R. E. (2014). Multivariate Data Analysis (7 $^{\text {th }}$ ed.). UK: Pearson Education Limited.

Hillman, A. J. (2005). Politicians on the board of directors: Do connections affect the bottom line? Journal of Management, 31, 464-481.

Houston, J. F., Jiang, L., Lin, C., \& Ma, Y. (2014). Political connections and the cost of bank loans. Journal of Accounting Research, 52(1), 193-243.

Ikatan Akuntan Indonesia (IAI). (2016). PSAK 7 (adjusted 2015 edition) - Pengungkapan pihakpihak berelasi. Retrieved from http://iaiglobal.or.id/v03/standar-akuntansi-keuangan/ pernyataan-sak-12-psak-7-pengungkapan-pihakpihak-berelasi

Islaqm, M. R. (2018). Sample size and its role in Central Limit Theore m (CLT ). Computational and Applied Mathematics Journal, 4(1), 1-7.

Jian, M., \& Wong, T. J. (2003). Earnings management and tunneling through RPTs: Evidence from Chinese corporate groups. SSRN Electronic Journal. doi: 10.2139/ssrn.424888

Jian, M., \& Wong, T. J. (2010). Propping through RPTs. Review of Accounting Studies, 15, 70-105. Johnson, S., LaPorta, R., Lopez-de-Silanes, F., \& Shleifer, A. (2000). Tunneling. The American Economic Review, 90(2), 22-27.

Kohlbeck, M., \& Mayhew, B. W. (2010). Valuation of firms that disclose RPTs. Journal of Accounting and Public Policy, 29(2), 115-137. 
Leuz, C., \& Oberholzer-Gee, F. (2006). Political relationships, global financing, and corporate transparency: Evidence from Indonesia. Journal of Financial Economics, 81, 422-439.

Lin, W. Y., Liu, Y. A., \& Keng, I. (2010). RPTs, firm performance and control mechanisms: Evidence from Taiwan. International Research Journal of Finance and Economics-Issue, 35, 82-98.

Ling, L., Zhou, X., Liang, Q., Song, P., \& Zeng, H. (2016). Political connections, overinvestments and firm performance: Evidence from Chinese listed real estate firms. Finance Research Letters, 18, 328-333.

Liu, C., Uchida, K., \& Yang, Y. (2012). Corporate governance and firm value during the global financial crisis: Evidence from China. International Review of Financial Analysis, 21, 70-80.

Financial Services Authority (OJK). (2009). Decree of the Chairman of the Capital Market and Financial Institution Supervisory Agency No. KEP-412/BL/2009 concerning affiliated transactions and conflicts of interest of certain transactions. Retrieved from https://www.ojk.go.id/Files/201401/IXE1_1389000017.pdf

Financial Services Authority (OJK). (2010). Capital Market and Financial Institution Supervisory Agency Decree No. Kep-554 / BL / 2010 concerning change in decree fo the charirman of capital market spaervisory agency number 06/PM/2000 concerning Amendment to Rule Number VIII.G.7 concerning Guidelines for the Presentation of Financial Statements. Retrieved from https://www.martinaberto.co.id/download/Peraturan _Bapepam/VIII.G.7_Pedoman_Penyajian_Laporan_Keuangan.pdf

Nekhili, M., \& Cherif, M. (2011). Related parties transactions and firm's market value: The French case. Review of Accounting and Finance, 10(3), 291-315.

Pizzo, M. (2013). RPTs under a contingency perspective. Journal of Management and Governance, 17, 309-330.

Sari, R. C., Fatimah, P. L. R., \& Djajadikerta, H. G. (2016). Development of tunneling detection model: A new corporate performance improvement. Jurnal Pengurusan, 48, 1-20.

Sun, P., Hu, H. W., \& Hillman, A. J. (2016). The dark side of board political capital : Enabling blockholder rent appropriation. Academy of Management Journal, 59(5), 1801-1822.

Supatmi, Sutrisno, Saraswati, E., \& Purnomosidhi, B. (2019). The effect of RPTs on firm performance : the moderating role of political connection in Indonesia banking. Business: Theory and Practice, 20, 81-92.

Tambunan, E., Martua, Siregar, H., Manurung, A. M., \& Priyarsono, D. S. (2017). RPTs and firm value in the business groups in the Indonesia Stock Exchange. Journal of Applied Finance \& Banking, 7(3), 1-20.

Tsai, C. C., Chang, L. E., \& Chang, Y. L. (2015). RPTs and corporate value. Journal of Economics, Business and Management, 3(10), 924-928.

Utama, C. A., \& Utama, S. (2014). Corporate governance, size and disclosure of RPTs, and firm value: Indonesia evidence. International Journal of Disclosure and Governance, 11(4), 341-365.

Utama, S., Utama, C. A., \& Yuniasih, R. (2010). RPT-efficient or abusive: Indonesia evidence. Asia Pacific Journal of Accounting and Finance, 1(1), 77-102.

Villalonga, B., \& Amit, R. (2006). How do family ownership, management, and control affect firm value? Journal of Financial Economics, 80, 385-417.

Wahab, E. A. A., Haron, H., Lok, C. L., \& Yahya, S. (2011). Does corporate governance matter? Evidence from RPTs in Malaysia. Advances in Financial Economics, 14, 131-164.

Wong, R. M. K., Kim, J. B., \& Lo, A. W. Y. (2015). Are related-party sales value-adding or value- 
destroying? Evidence from China. Journal of International Financial Management and Accounting, 26(1), 1-38.

Wu, W., Wu, C., Zhou, C., \& Wu, J. (2012). Political connections, tax benefits, and firm performance: Evidence from China. Journal of Accounting and Public Policy, 31(3), 277300 .

\section{APPENDIX}

Appendix A: Examples of the determination of the political connection index

\begin{tabular}{|c|c|c|c|}
\hline Firm & $\begin{array}{l}\text { The presence } \\
\text { of political } \\
\text { connections } \\
\text { (PCDUM) }\end{array}$ & $\begin{array}{c}\text { Index of } \\
\text { political } \\
\text { connections } \\
(\text { PCI) }\end{array}$ & Explanation \\
\hline $\begin{array}{l}\text { Buana } \\
\text { Finance Tbk. } \\
\text { (BBLD) }\end{array}$ & $\mathrm{PC}$ is present & Ln5 $=1.609$ & $\begin{array}{l}\text { As an independent commissioner (supervisory board } \\
\text { member) and a member of the audit committee, } \\
\text { Corneiles Tedjo Endriyarto worked as a senior auditor } \\
\text { at the Inspectorate General of Ministry of Finance } \\
\text { from } 1994 \text { to } 2014 \text {. }\end{array}$ \\
\hline $\begin{array}{l}\text { Chandra Asri } \\
\text { Petrochemical } \\
\text { Tbk. (TPIA) }\end{array}$ & $\mathrm{PC}$ is present & $\operatorname{Ln} 22=3.091$ & $\begin{array}{l}\text { The firm has three politically-connected personnel, } \\
\text { including Djoko Suyanto, Agus Salim Pangestu, and } \\
\text { Baritono Pangestu. As the president commissioner and } \\
\text { also an independent commissioner, Djoko Suyanto } \\
\text { was the Indonesian Coordinating Minister of Politics, } \\
\text { Law, and Security from } 2009 \text { to } 2014 \text { and the Chief of } \\
\text { Staff of the Indonesian National Armed Forces (TNI- } \\
\text { Tentara Nasional Indonesia) from } 2006 \text { to } 2008 . \\
\text { Meanwhile, as supervisory board members, Agus } \\
\text { Salim Pangestu and Baritono Pangestu are sons of } \\
\text { Prajogo Pangestu who were very close with ex- } \\
\text { President Soeharto (Fisman, 2001; Leuz and } \\
\text { Oberholzer-Gee, 2006). }\end{array}$ \\
\hline $\begin{array}{l}\text { JAPFA } \\
\text { Comfeed } \\
\text { Indonesia } \\
\text { Tbk. (JPFA) }\end{array}$ & $\mathrm{PC}$ is present & $\operatorname{Ln} 8=2.079$ & $\begin{array}{l}\text { As the president commissioner and a member of } \\
\text { Nomination and Remuneration Committee, H. } \\
\text { Syamsir Siregar was a military officer until } 1996 \text { with } \\
\text { the highest position of the Head of Military } \\
\text { Intelligence Agency (Badan Intelijen ABRI). He was } \\
\text { also the Head of the National Intelligence Agency. }\end{array}$ \\
\hline $\begin{array}{l}\text { Voksel } \\
\text { Electric Tbk. } \\
\text { (VOKS) }\end{array}$ & $\mathrm{PC}$ is present. & $\operatorname{Ln} 7=1.946$ & $\begin{array}{l}\text { As the president commissioner, Kumhal Djamil held a } \\
\text { position of the Assistant of Coordinating Minister of } \\
\text { National Production Development, Marketing, and } \\
\text { Distribution in 1993-1996 and was an assistant of } \\
\text { Ministry of Coordination of Industry in 1996-1998. }\end{array}$ \\
\hline
\end{tabular}

